\title{
4.- MUJERES JÓVENES Y CONSTRUCCIÓN DE OCUPACIONES TRANSGRESORAS: UNA MIRADA DE LAS TRAYECTORIAS DE VIDA DESDE TERAPIA OCUPACIONAL
}

\author{
YOUNG WOMEN AND CONSTRUCTION OF TRANSGRESSIVE OCCUPATIONS: A \\ LOOK AT LIFE TRAJECTORIES FROM OCCUPATIONAL THERAPY
}

\section{RESUMEN}

Esta investigación busca conocer desde una terapia ocupacional crítica cómo se construyen las ocupaciones transgresoras en mujeres jóvenes con conductas de infracción de ley mediante el relato de sus trayectorias de vida, con énfasis en la perspectiva de género poco explorada a nivel disciplinar. Para aproximarse a la información, se realizan entrevistas en profundidad con cuatro jóvenes pertenecientes al programa de rehabilitación GES menores de 20 años, de un centro de salud mental comunitario, del sector sur oriente de la ciudad de Santiago. Durante el proceso realizado, se logra acceder a la configuración de estos hechos a partir de la validación de las experiencias de las participantes, como forma valiosa y real de producir conocimiento que contribuya al progreso en el área.

Se logra identificar la vulnerabilidad de los territorios, elementos de sus historias individuales y otros factores asociados a la problemática; la importancia de componentes culturales, sociales - contextuales, el rol de pares, familia y figuras masculinas. Se evidencian dificultades de acceso y participación libre en ocupaciones con significado que favorezcan la salud y bienestar de las jóvenes, y la implicancia de las instituciones comunitarias especializadas en atender a la rehabilitación de estas situaciones. La trascendencia de vivencias negativas durante el ciclo vital, y como se estructura e integra la perspectiva de género, y sus percepciones personales a través de construcciones socio históricas y culturales hegemónicas. Exponiendo la necesidad de generar investigaciones específicas que aporten al desarrollo teórico del concepto de ocupación transgresora, actualmente no abordado por la profesión.

\section{PALABRAS CLAVE}

mujeres jóvenes, ocupación transgresora, infracción de ley, trayectorias de vida, Terapia Ocupacional, perspectiva de género.

\begin{abstract}
This research seeks to know from a critical occupational therapy, how transgressive occupations are built in young women with behaviors of law violation through the story of their life trajectories, with emphasis on the gender perspective little explored at the disciplinary level. To get closer to the information, in-depth interviews are conducted with four young people belonging to the Ges rehabilitation program under 20, from a community mental health center in the south east sector of the city of Santiago. During the process, it is possible to access the configuration of these facts based on the validation of the participants' experiences, as a valuable and real way to produce knowledge that contributes to progress in the area.

It is possible to identify the vulnerability of the territories, elements of their individual histories and other factors associated with the problem; the importance of cultural, social-contextual components, the role of peers, family and male figures. There are evident difficulties of access and free participation in occupations with meaning that favor the health and well-being of young women, and the implication of community
\end{abstract}


institutions specialized in dealing with the rehabilitation of these situations. The transcendence of negative experiences during the life cycle, and how the gender perspective is structured and integrated, and their personal perceptions through socio-historical and cultural hegemonic constructions. Exposing the need to generate specific research that contributes to the theoretical development of the concept of transgressive occupation, currently not addressed by the profession.

\section{KEYWORDS}

young women, transgressive occupations, infringement of law, life trajectories, occupational therapy, gender perspective.

Paula Margarita De la Fuente Pérez

Terapeuta ocupacional, Licenciada en Terapia Ocupacional. Diploma en Rehabilitación Basada en la Comunidad, Diploma en Neuropsicología Infantil, Magister en Ocupación y Terapia Ocupacional. Terapeuta ocupacional en Cosam La Bandera, Académica Instructor adjunto Departamento de Psiquiatría y salud mental, Universidad de Chile. pauladelafuentep@gmail.com

Directora de Tesis: T.O. Prof. Laura Rueda Castro Co dirección: T.O. Mónica Palacios 